\title{
JUlita MAKaro
}

UNIWERSYTET WROCEAWSKI

E-MAIL: JULITA.MAKARO@UWR.EDU.PL

\section{POGRANICZE POLSKO-NIEMIECKIE W REFLEKSJI SOCJOLOGICZNEJ Z PERSPEKTYWY ĆWIERĆWIECZA}

\section{Wprowadzenie}

Socjologowie nie pojawili się na pograniczu zachodnim Polski z początkiem lat dziewięćdziesiątych; data ta ma jednak swoje uzasadnienie symboliczne i merytoryczne - stąd sygnalizowana w tytule dwudziestopięcioletnia perspektywa dla prowadzonych w artykule rozważań. Ćwierćwiecze wydaje się być wystarczającym już czasem upoważniającym do poszukiwania pewnych reguł, tendencji, prawideł określających merytoryczny i instytucjonalny rozwój socjologicznej refleksji nad pograniczem polsko-niemieckim. Można również uznać, że rocznica jest dobrym powodem, a nawet zobowiązuje do podjęcia próby stworzenia podsumowań i syntez.

Zanurzenie się w jakimś zjawisku nie zawsze umożliwia jego całościowy ogląd, trafne rozpoznanie, adekwatne interpretacje. W takiej sytuacji są po trosze badacze pogranicza zachodniego - bez względu na to, czy przyjmują metodologię emic czy etic, interesują ich te same zjawiska, uczestniczą we wspólnych konferencjach, publikują we wspólnych tomach, czytają nawzajem swoje opracowania, ale chyba nie są w stanie (poza specjalnie temu poświęconymi przedsięwzięciami badawczymi) syntetyzować całości na bieżąco. Dlatego ideą przyświecającą powstaniu niniejszego opracowania jest chęć podsumowania dotychczasowego dorobku socjologii pogranicza zachodniego, zarówno w jej obszarze przedmiotowym, jak i instytucjonalnym. Pytania, na które będę poszukiwać odpowiedzi w prezentowanym artykule, są następujące: Jak, w świetle publikacji, prezentują się problemy i tematy podejmowane $\mathrm{w}$ ramach socjologii pogranicza polsko-niemieckiego, jak określany jest zakres tej refleksji oraz jak instytucjonalizowała się ta dziedzina. 


\section{Rozstrzygnięcia teoretyczno-metodologiczne}

Na potrzeby niniejszej wypowiedzi przyjmuję, że badania nad pograniczem polsko-niemieckim rozpoczęły się w następstwie przeobrażeń społeczno-politycznych przełomu lat osiemdziesiątych i dziewięćdziesiątych, których najważniejszymi konsekwencjamibyło otwarcie granici wewnętrzne zmiany polityczne w graniczących ze sobą krajach. O specyfice i innowacyjności tej aktywności naukowców świadczy zwrócenie uwagi na „przemiany społeczne dokonujące się na polsko-niemieckim pograniczu” [Sakson 2002: 76], ale również przywrócenie do refleksji socjologicznej kategorii pogranicza polsko-niemieckiego, które zastąpiło, a może uzupełniło, kategorię Ziem Zachodnich i Północnych (ZZiP). Relacji między obiema kategoriami należy poświęcić kilka słów, gdyż nie jest ona wcale oczywista. Andrzej Sakson wśród czterech nowych obszarów badawczych ZZiP wskazał przywołane powyżej procesy społeczne zachodzące na pograniczu [Sakson 2002], zaś w innym miejscu mówi nawet o zastąpieniu paradygmatu „integracji ZZiP” innymi perspektywami [Sakson 2011: 84]. Polemiczną koncepcję prezentuje Leszek Gołdyka [2013: 68-69], który uważa, że „Socjologia pogranicza (zachodniego), choć powiązana z socjologią Ziem Odzyskanych, nie jest - z jednym wyjątkiem - co do przedmiotu zainteresowań $\mathrm{z}$ nią tożsama, nie jest jej kontynuacją w innej szacie, lecz osobną dziedziną uwzględniającą jej dorobek." Spojrzenie na przedsięwzięcia naukowe podejmowane po przełomie lat dziewięćdziesiątych pokazuje, że socjologia ZZiP nie „umarła”, a socjologia pogranicza (w tym polsko-niemieckiego), mierzona choćby liczbą publikacji, rozwija się - zatem postulat Zbigniewa Kurcza [1998: 22], by kategorię ZZiP zastąpić kategorią pogranicza, którą autor uznaje za „najważniejszą w testamencie Ziem Zachodnich i Północnych”, w praktyce naukowej spełnił się częściowo. Uwzględniając odmienności przedstawionych poglądów i próbując je "pogodzič" można chyba zaryzykować twierdzenie, że w interesującym nas obszarze dominującą wykładnią badawczą do lat dziewięćdziesiątych była perspektywa ZZiP, w czasach najnowszych zaś częściej wykorzystywana jest perspektywa pogranicza.

Wnioskowanie o kondycji socjologii pogranicza polsko-niemieckiego można oprzeć na publikacyjnym dorobku dyscypliny - tematyka, liczba, autorstwo oraz miejsce ogłoszenia drukiem mogą być dobrymi wskaźnikami jej rozwoju. Zamysł teoretycznie poprawny oraz czytelny w praktyce okazuje się jednocześnie dość złożony, a główną trudność stanowi rozstrzygnięcie co ma stanowić uniwersum materiału do analizy, innymi słowy - które publikacje włączyć, a które wyłączyć ze zbioru konstytuującego 
dorobek socjologii pogranicza zachodniego. Ponieważ rozstrzygnięcie tego dylematu będzie rzutować na wyniki analiz i zakres wniosków, doborowi próby poświęcono duży fragment artykułu.

Kwalifikując publikacje do analizy jako wpisujące się w socjologiczną refleksję nad pograniczem polsko-niemieckim starałam się zawęzić rozważania do „»czystej« socjologii pogranicza” [Zielińska 2003: 137] zachodniego, dlatego też nie zostały włączone do kompletowanego uniwersum publikacje dotyczące Ziem Zachodnich i Północnych (nawet jeśli ich fragmenty odnosiły się do analizowanego pogranicza). Pominięte zostały również liczne publikacje dotyczące pogranicza w ogóle oraz omawiające kilka/wszystkie polskie pogranicza (trudno jednoznacznie ustalić, jak intensywna obecność tematu pogranicza zachodniego w poszczególnych opracowaniach miałaby decydować o jego zakwalifikowaniu do dorobku socjologii pogranicza zachodniego). Nie weszły do zbioru również publikacje o stosunkach polsko-niemieckich, o ile nie były identyfikowane na pograniczach.

Tworząc zbiór wypowiedzi będący przedmiotem analizy, w pierwszym rzędzie wsłuchiwałam się $\mathrm{w}$ głos autora, deklarującego swoje zainteresowanie pograniczem zachodnim, przede wszystkim w tytule opracowania, później dopiero w treści. Zderzenie anonsu autorskiego z jego rozwinięciem powodowały kolejne rozterki, które wpisują w toczącą się dyskusję o przedmiocie socjologii pogranicza i jego zakresie .

W większości przypadków dzieł autorzy uznają za zasadne podkreślenia znaczenia pogranicza polsko-niemieckiego dla ich rozważań, poprzez sygnalizowanie tego pola semantycznego w tytule. I to wystarczało do zakwalifikowania publikacji do opracowywanego zbioru, choć czasem po lekturze tekstu można było dojść do wniosku, że pogranicze jest tu raczej pretekstem niż istotą rozważań. Tym samym w zgromadzonym materiale odnajdujemy echa dyskusji o istocie socjologii pogranicza - czy badać zjawiska specyficzne dla poszczególnych pogranicz, czy też - uznając pogranicze za zmienną niezależną - poszukiwać efektu pogranicza i badać wszelkie zjawiska na nim zachodzące? ${ }^{1}$.

Drugi rodzaj wątpliwości dotyczył interpretacji geograficznych deklaracji autorów, którzy swoje analizy odnosili do konkretnych miast i regionów. O ile leżące na granicy euroregiony oraz miasta podzielone nie generują wątpliwości co do ich pogranicznej proweniencji (ale porównywanie

Nie przywołuję w tym miejscu konkretnych publikacji, ale odsyłam czytelnika do licznych wypowiedzi tak uznanych badaczy pogranicza, jak L. Gołdyka, Z. Kurcz, A. Sadowski, w których składali różne autorskie propozycje teoretyczne, i których ewolucję można tam również śledzić. 
w jednym artykule o pograniczu polsko-niemieckim Poznania, Opola, Szczecina i Zielonej Góry już tak), to kategorie Ziemi Lubuskiej lub Zachodniopomorskiego bywają kłopotliwe. Oczywiście, należy uznać analityczną przydatność koncepcji pogranicza zachodniego wyznaczanego przez trzy województwa, lub pięć subregionów, albo dziewięć powiatów [Gołdyka 2013: 77-78] i przyjąć, że rozważania odnoszące się do tak wyodrębnionych obszarów administracyjnych mieszczą się w refleksji naukowej omawianej w tym artykule. Jednak możliwa jest równocześnie sytuacja, w której analizy obejmujące województwo lubuskie lub zachodniopomorskie są prowadzone w innym porządku teoretycznym (np. paradygmatu modernizacyjnego, a nie pogranicznego), zatem ewentualna ich „pograniczność” nie jest oczywista i geograficznie dana, ale winna być przez autora nie tylko zgłoszona, ale i uzasadniona. Innymi słowy badania prowadzone na terenach przygranicznych nie muszą wpisywać się w przedmiot socjologii pogranicza.

Podsumowując rozterki pojawiające się podczas tworzenia zbioru publikacji składających się na dorobek socjologii pogranicza polsko-niemieckiego, należy przywołać dwa dyskutowane problemy - teoretyczny charakter pogranicza oraz jego zasięg. Odnosząc się do pierwszego, można zaryzykować tezę, iż po wielekroć zdefiniowano pojęcie pogranicza zachodniego, jak i określono co może być przedmiotem jego badania ${ }^{2}$. Istnienie wielu koncepcji teoretycznych pogranicza - jakże charakterystyczne dla badań społecznych - nie unieważnia poszczególnych i powinno być w krytyczny sposób przez badaczy uwzględniane. Podobnie rzecz ma się z zasięgiem pogranicza (polsko-niemieckiego) - brak jednoznacznych rozstrzygnięć determinuje różne stanowiska badawcze. Zapewne większą akceptację zyskuje koncepcja „powiatowa”, większe wątpliwości wzbudza koncepcja „wojewódzka” [Gołdyka 2013], ale uznania wymaga również założenie o przesuwaniu się pogranicz [Kurcz 2011] - dlatego wybór poszczególnych ujęć wymaga uargumentowania, a nie milczącego przyjęcia. Być może to nie słabość teoretyczna dyscypliny, ale zbyt duża dezynwoltura badaczy, którzy bez dostatecznego wyartykułowania założeń wpisują swoje dociekania teoretyczne i empiryczne w perspektywę pogranicza, w tym wypadku - zachodniego. Nie o szczególny puryzm tu idzie, ale o podkreślenie znacze-

Syntetycznie zebrał dorobek socjologii pogranicza (ze szczególnym uwzględnieniem polsko-niemieckiego) Leszek Gołdyka [2013]w książce Pogranicze polsko-niemieckie jako przestrzeń socjalizacji, w której dokonał obszernego przeglądu stanowisk i koncepcji, dlatego nie odsyłam do poszczególnych publikacji wybranych autorów, w których swoje pomysły przedstawiają, korygują, ale do tego zbiorczego opracowania. 
nia całego środowiska naukowego, którego rola w kształtowaniu dyscypliny jest podstawowa - może ono bardziej uważnie i wymagająco spoglądać na kwestie merytoryczne (kwalifikowanie referatów na konferencje) i instytucjonalizujące (publikowanie różnych refleksji pod szyldem pogranicza zachodniego).

Przedstawiając czytelnikowi poczynione rozstrzygnięcia w procedurze doboru próby, pragnę zaznaczyć, że są one dyskutowalne i mogą być modyfikowane. Niedoskonałość omówionej procedury doboru próby była niwelowana wysiłkiem podjętym na rzecz jak najpełniejszej reprezentacji tekstów według wspomnianych kryteriów. Dlatego przyznając, iż nie jest to dobór wyczerpujący (możliwa, a nawet wysoce prawdopodobna jest sytuacja, w której, mimo długich poszukiwań, do jakichś publikacji spełniających kryteria nie udało mi się dotrzeć), zaakcentować należy, że podjęto wszelkie starania (np. przegląd bibliografii analizowanych publikacji) dla jego nasycenia i reprezentatywności.

\section{Wybrane aspekty instytucjonalizacji socjologii pogranicza polsko-niemieckiego}

Dość oczywistą konstatacją jest stwierdzenie, że zainteresowanie nowymi zjawiskami na zachodnim pograniczu Polski było szczególne w blisko położonych ośrodkach naukowych - w Szczecinie, Zielonej Górze, Poznaniu, Wrocławiu. To właśnie tam prowadzona działalność badawcza, konferencyjna i publikacyjna stanowi gros dorobku będącego przedmiotem prowadzonych tu rozważań. Instytucjonalizację socjologii pogranicza polsko-niemieckiego można próbować opisać na różne sposoby, w tym miejscu jej wskaźnikami będą: liczba publikacji, miejsce ogłaszania drukiem opracowań naukowych oraz aktywność piśmiennicza poszczególnych autorów podejmujących refleksję na ten temat.

Wielość publikacji dotyczących zachodniego pogranicza i dynamika ich przyrostu w ciągu ćwierćwiecza może stanowić odzwierciedlenie ewolucji zainteresowania tematem, ewentualnie jego rosnącą popularność, być może wagę poruszanych problemów. Argumentację merytoryczną należy jednak zderzyć z technokratyczną - liczba publikacji (będąca tu wskaźnikiem rozwoju socjologii pogranicza polsko-niemieckiego) w poszczególnych latach jest również pochodną mechanizmów od socjologów niezależnych. Szczególna aktywność twórcza ma miejsce przy okazji organizowania konferencji, publikacyjna jest widoczna gdy ukazuje się tom zawierający zbiór artykułów, w innych wypadkach autorzy skazani są na obowiązujące cykle 
recenzyjno-wydawnicze. A dla wszystkich wymienionych wspólny mianownik często stanowią trudności finansowe i organizacyjne. Dlatego też patrząc na prezentowane dane należy mieć na uwadze obie determinanty.

Tabela 1. Liczba publikacji dotyczących pogranicza polsko-niemieckiego w przedziałach czasowych

\begin{tabular}{|l|c|c|c|}
\hline \multicolumn{1}{|c|}{ Lata } & Częstość & Procent & $\begin{array}{c}\text { Procent } \\
\text { skumulowany }\end{array}$ \\
\hline $1990-1995$ & 14 & 7,3 & 7,3 \\
\hline $1996-2000$ & 42 & 21,9 & 29,2 \\
\hline $2001-2005$ & 53 & 27,6 & 56,8 \\
\hline $2006-2010$ & 46 & 24,0 & 80,7 \\
\hline $2011-2014$ & 37 & 19,3 & 100,0 \\
\hline Ogółem & 192 & 100,0 & $x$ \\
\hline
\end{tabular}

x oznacza - wypełnienie rubryki jest niemożliwe lub niecelowe.

Źródło: badania własne.

Poza pierwszymi latami, kumulatywny przyrost danych i analiz o pograniczu polsko-niemieckim wyrażający się liczbą publikacji postępuje mniej więcej równomiernie, a ponad połowa dotychczasowych publikacji powstała w pierwszych piętnastu latach wyodrębnionego okresu. Szczególne zainteresowanie pograniczem zachodnim przypada na okres przedakcesyjny, wówczas traktowane było ono jako laboratorium nadchodzącej integracji europejskiej generujące wiele nowych zjawisk i procesów wymagających rozpoznania.

Tabela 2. Liczba publikacji dotyczących pogranicza polsko-niemieckiego w poszczególnych latach

\begin{tabular}{|l|c|c|c|}
\hline \multicolumn{1}{|c|}{ Rok } & Częstość & Procent & $\begin{array}{c}\text { Procent } \\
\text { skumulowany }\end{array}$ \\
\hline 1991 & 1 & 0,5 & 0,5 \\
\hline 1992 & 4 & 2,1 & 2,6 \\
\hline 1993 & 3 & 1,6 & 4,2 \\
\hline 1994 & 4 & 2,1 & 6,3 \\
\hline 1995 & 2 & 1,0 & 7,3 \\
\hline 1996 & 5 & 2,6 & 9,9 \\
\hline 1997 & 8 & 4,2 & 14,1 \\
\hline 1998 & 4 & 2,1 & 16,1 \\
\hline
\end{tabular}




\begin{tabular}{|l|r|r|c|}
\hline \multicolumn{1}{|c|}{ Rok } & Częstość & Procent & Procent skumulowany \\
\hline 1999 & 20 & 10,4 & 26,6 \\
\hline 2000 & 5 & 2,6 & 29,2 \\
\hline 2001 & 27 & 14,1 & 43,2 \\
\hline 2002 & 8 & 4,2 & 47,4 \\
\hline 2003 & 8 & 4,2 & 51,6 \\
\hline 2004 & 5 & 2,6 & 54,2 \\
\hline 2005 & 5 & 2,6 & 56,8 \\
\hline 2006 & 7 & 3,6 & 60,4 \\
\hline 2007 & 16 & 8,3 & 68,8 \\
\hline 2008 & 5 & 2,6 & 71,4 \\
\hline 2009 & 14 & 7,3 & 78,6 \\
\hline 2010 & 4 & 2,1 & 80,7 \\
\hline 2011 & 13 & 6,8 & 87,5 \\
\hline 2012 & 8 & 4,2 & 91,7 \\
\hline 2013 & 5 & 2,6 & 94,3 \\
\hline 2014 & 11 & 5,7 & 100,0 \\
\hline Ogółem & 192 & 100,0 & X \\
\hline
\end{tabular}

Źródło: badania własne.

Roczna statystyka pokazuje dwa zjawiska - po pierwsze, można powiedzieć, że średnia dynamika wydawnicza to kilka opracowań rocznie (bez rozróżnienia na artykuły i monografie), po drugie, w różnych interwałach dają się zaobserwować lata „tłuste”, w których dorobek piśmienniczy znacznie wzrasta. W roku 1999 stało się to głównie za sprawą tomu Transgraniczność w perspektywie socjologicznej. Kontynuacje, jak również Pogranicze $z$ Niemcami a inne pogranicza Polski, natomiast w roku 2001 zmaterializowały się w formie książkowej trzy pozycje: Transgraniczność $w$ perspektywie socjologicznej. Kontynuacje i wyzwania, Pogranicza etniczne w Europie. Harmonia i konflikty oraz Problemy społeczno-gospodarcze na pograniczach; w roku 2007 ukazały się Transgraniczność w perspektywie socjologicznej. Pogranicza Polski i integrującej się Europy oraz Społeczeństwo pogranicza polsko-niemieckiego. Wyzwania i dylematy. W roku 2009 żaden z tomów zbiorowych nie był dominujący, ale za kolejny pik z roku 2011 są „odpowiedzialne" dwie książki: Zgorzelec jako miasto pograniczne w opiniach jego mieszkańców oraz Polsko-niemieckie transgranicza - rozmyte konfiguracje tożsamości; natomiast w 2014 roku analogiczne funkcje pełnią Transgraniczność w perspektywie socjologicznej. Pogranicza i centra współczesnej Europy 
oraz Polskie pogranicza $w$ procesie przemian, tom 3. Do zasygnalizowanej powyżej szczególnej roli niektórych inicjatyw wydawniczych powrócę jeszcze w dalszej części wypowiedzi. Połowa dotychczasowych publikacji o zachodnim pograniczu Polski ukazała się przed 2004 rokiem, zatem w okolicach „półmetku” omawianej perspektywy czasowej.

$\mathrm{Na}$ rozwój subdyscypliny naukowej można spojrzeć również w perspektywie instytucji przez nią wytworzonych, umożliwiających jej funkcjonowanie. Socjologia pogranicza polsko-niemieckiego nie posiada, ale chyba też nie potrzebuje, własnych narzędzi i z powodzeniem korzysta z zasobów socjologii pogranicza. Ta ostatnia może pochwalić się wydawanym w Białymstoku czasopismem „Pogranicze. Studia Społeczne”, które po raz pierwszy ukazało się w 1992 roku, organizowaną przez Instytut Socjologii Uniwersytetu Zielonogórskiego cykliczną konferencją i towarzyszącą jej publikacją Transgraniczność w perspektywie socjologicznej, która została zainicjowana w 1996 roku. W kolejnym roku w Instytucie Socjologii Uniwersytetu Wrocławskiego powołano Zakład Socjologii Pogranicza, który od 2000 roku organizuje cykl konferencji „Polskie pogranicza w procesie przemian"3. Wszystkie przywołane inicjatywy pokazują proces tworzenia się tożsamości subdyscypliny poprzez wyposażenie jej w instytucje dla niej specyficzne. $\mathrm{Z}$ wymienionych inicjatyw badacze pogranicza polsko-niemieckiego korzystają, co widać w dystrybucji ich dorobku publikacyjnego. Większość artykułów przypisanych przeze mnie do zasobów socjologii pogranicza polsko-niemieckiego została pomieszczona w tomach monograficznych o pograniczach.

Dane prezentowane w tabeli 3 pokazują zacną rolę, jaką w promocji dorobku socjologii pogranicza polsko-niemieckiego pełni cykl publikacji potocznie nazywany „transgranicznościami”4, artykuły wydane w czasopismach stanowią 20\% wszystkich publikacji. Wielość artykułów pochodzących z „Rocznika Lubuskiego” po raz kolejny pokazuje aktywność ośrodka zielonogórskiego.

Zilustrowane w tabeli 3 skupienie w kilku przestrzeniach wydawniczych dużej części wypowiedzi socjologów zajmujących się pograniczem zachodnim może być odczytane z jednej strony jako efektywne korzystanie z wykształconych przez subdyscyplinę kanałów komunikacyjnych, ułatwia-

Należy w tym miejscu również wspomnieć o tomach zbiorowych wydawanych przez IFiS PAN, które także są jednym z filarów instytucjonalizującej się socjologii pogranicza, w których jednak pogranicze polsko-niemieckie jest rzadko obecne.

4 Warto wspomnieć o przeobrażeniach, jakim podlega cały wspomniany cykl, spośród wyodrębnionych 56 artykułów 44 zostały opublikowane w latach 1996-2005. 
jące dotarcie do grona badaczy szczególnie zainteresowanych określoną problematyką, pozwalające zapoznać się z aktualnymi i reprezentatywnymi ustaleniami na dany temat osobom takiej wiedzy poszukującym. Z drugiej strony, taki stan rzeczy ogranicza wchodzenie w dyskusje toczone na szerszym polu socjologii, nieobecność tematu pogranicza polsko-niemieckiego w czasopismach ogólnosocjologicznych (wydawanych w ośrodkach innych, niż wymienione już jako aktywne w tym obszarze), utrudnia promowanie podejmowanej problematyki jako ważnej dla współczesnej rzeczywistości społecznej i uniemożliwia poddanie się szerszej krytyce ${ }^{5}$.

Tabela 3. Tytuły tomów i czasopism, w których zamieszczono artykuły zakwalifikowane do dorobku socjologii pogranicza zachodniego

\begin{tabular}{|l|c|c|}
\hline \multicolumn{1}{|c|}{ Tytuł } & Częstość & Procent \\
\hline Transgraniczność w perspektywie socjologicznej & 56 & 29,2 \\
\hline Polskie pogranicza w procesie przemian & 9 & 4,7 \\
\hline „Pogranicze. Studia Społeczne” & 5 & 2,6 \\
\hline „Opuscula Sociologica” & 9 & 4,7 \\
\hline „Przegląd Zachodni” & 7 & 3,6 \\
\hline „Rocznik Lubuski” & 17 & 8,9 \\
\hline „Sprawy Narodowościowe” & 1 & 0,5 \\
\hline Inne publikacje & 88 & 45,8 \\
\hline Ogółem & 192 & 100,0 \\
\hline
\end{tabular}

a Uwzględniono również artykuły z czasów, gdy czasopismo miało tytuł „Studia Sociologica”.

Źródło: badania własne.

Tabela 4. Rodzaj publikacji z uwzględnieniem miejsca ogłoszenia

\begin{tabular}{|l|c|c|}
\hline \multicolumn{1}{|c|}{ Miejsce publikacji } & Częstość & Procent \\
\hline Artykuł w tomie zbiorowym & 26 & 13,5 \\
\hline Artykuł w czasopiśmie & 42 & 21,9 \\
\hline $\begin{array}{l}\text { Artykuł w tomie monograficznym } \\
\text { o pograniczach }\end{array}$ & 108 & 56,3 \\
\hline Monografia & 16 & 8,3 \\
\hline Ogółem & 192 & 100 \\
\hline
\end{tabular}

Źródło: badania własne.

5 Choć trzeba przyznać, że jest to raczej problem całej subdyscypliny, żadne z polskich pograniczy nie jest $\mathrm{w}$ tym względzie szczególnie uprzywilejowane ani upośledzone. Być może ta nieobecność to funkcja heterogeniczności czasopism nieprofilowanych, za pożądany można by uznać numer „Kultury i Społeczeństwa” lub „Studiów Socjologicznych” poświęcony polskim pograniczom i je porównujący, ale pewnie jest to oczekiwanie niejednej subdyscypliny socjologicznej. 
Przyjmowane przez autorów strategie określające miejsce ogłoszenia swoich przemyśleń i wyników badań bywają bardzo różne, a wnioskując z efektu końcowego można stwierdzić, że tematyczne opracowania zbiorowe cieszą się ich dużym uznaniem. Jak pokazano w tabeli 4, ponad połowa artykułów ukazała się w monografiach wieloautorskich o pograniczach. Monografie autorskie, jako najbardziej wymagające i niedające się raczej porównywać ciężarem gatunkowym $\mathrm{z}$ artykułami naukowymi, stanowią niemal dziesiątą część wszystkich zasobów publikacyjnych omawianego tematu, a dynamika ich powstawania wzrosła - dwanaście ukazało się już w nowym tysiącleciu. Z jednej strony można powiedzieć, że pewne kwestie dojrzały i nabrzmiały na tyle, by mogły się stać przedmiotem pogłębionej i rozbudowanej analizy charakterystycznej dla monografii właśnie, zwieńczeniem długotrwałych badań uprzednio referowanych w artykułach, z drugiej natomiast trzeba przypomnieć, że rynek wydawnictw naukowych wyraźnie się ożywił i zróżnicował. Nie należy też zapominać o rosnącym znaczeniu w naukowej buchalterii punktów przyznawanych za różne publikacje i relatywnie słabym premiowaniu (w budzącym wiele wątpliwości procesie wyceny pracy naukowej) monografii autorskich.

Tabela 5. Liczba publikacji najbardziej aktywnych autorów

\begin{tabular}{|l|c|c|c|}
\hline Autor & Częstość & Procent & $\begin{array}{c}\text { Procent } \\
\text { skumulowany }\end{array}$ \\
\hline A & 21 & 10,9 & 10,9 \\
\hline B & 14 & 7,3 & 18,2 \\
\hline C & 13 & 6,8 & 25 \\
\hline D & 12 & 6,3 & 31,3 \\
\hline E & 10 & 5,2 & 36,5 \\
\hline F & 9 & 4,7 & 41,2 \\
\hline G & 7 & 3,6 & 44,8 \\
\hline H & 7 & 3,6 & 48,4 \\
\hline I & 6 & 3,1 & 51,5 \\
\hline J & 5 & 2,6 & 54,1 \\
\hline K & 4 & 2,1 & 56,2 \\
\hline L & 4 & 2,1 & 58,3 \\
\hline $\mathbf{L}$ & 4 & 2,1 & 60,4 \\
\hline M & 4 & 2,1 & 62,5 \\
\hline
\end{tabular}

Źródło: badania własne. 
Jak pokazują dane w tabeli 5, trzecia część literatury przedmiotu została napisana przez czterech autorów, połowa - przez dziewięciu. Te wartości nabierają szczególnego znaczenia wobec faktu, że analizowane uniwersum omawianych tekstów zostało wytworzone przez osiemdziesięciu dziewięciu autorów (w tabeli 5 przedstawiono tylko czternastu, którzy stworzyli ponad trzy publikacje). Należy wskazać na kilka okoliczności pozwalających zrozumieć taką właśnie konstelację. Po pierwsze, podkreślenia wymaga, że podjęto wąski temat, będący (zaledwie) jednym z obszarów młodej subdyscypliny, jaką jest socjologia pogranicza (choć trzeba wspomnieć, że pogranicza bardzo istotnego, do czego powrócę jeszcze w zakończeniu). Po drugie, poczynione obliczenia uwzględniały również prace współautorskie, co dla analiz ilościowych wydaje się być znaczącym kryterium oceny ostatecznych ustaleń. Po trzecie, prezentowany powyżej ilościowy opis zjawiska jest silnie determinowany przez rodzaj projektów badawczych będących kanwą wypowiedzi naukowych - ich czasu trwania, zakresu problemowego, powtarzalności oraz praktyk autorów dotyczących promowania i rozpowszechniania uzyskanych wyników. Przyczynkowe badania obejmujące jakieś wąskie zagadnienie zazwyczaj materializują się w jednym, dwóch artykułach, a prowadzone przez kilka lat, na różnych próbach, w większym zespole badawczym pomiary i ich analizy przybierają kształt kilku raportów cząstkowych i stanowią podstawę wielu odrębnych artykułów. Tym samym powyższe dane opisują li tylko ilościowy aspekt aktywności badaczy zajmujących się pograniczem polsko-niemieckim, nie uwzględniając ich wewnętrznego problemowego zróżnicowania.

\section{Obszary zainteresowań socjologii pogranicza polsko-niemieckiego}

Aby uzyskać bardziej wyczerpujący obraz socjologii pogranicza zachodniego warto podjąć próbę rekonstrukcji jej przedmiotu. By wyzwanie to skonkludowało się sensownym i czytelnym opisem, bardzo niejednorodne treści wypowiedzi naukowych należałoby sprowadzić do kilku ogólnych kategorii - wielość analizowanych publikacji sprawy nie ułatwia. Próba odtworzenia głównych tematów rzuca badacza w bardzo różne porządki: aktorów, zjawisk, procesów na pograniczu obecnych. Stworzenie typologii jest raczej niemożliwe. Autorzy raz eksponują przedmiot badań - relacje międzysąsiedzkie, ponadgraniczną współpracę, stereotypy, patologie, $\mathrm{w}$ innych wypadkach czynią nadrzędnym przedmiotem dociekań naukowych podmiot tych procesów - mieszkańców, młodzież, elity. W jakiejś mierze jest to odzwierciedleniem mnogości obszarów socjologii per se. 
W próbie posegregowanie dorobku socjologii pogranicza polsko-niemieckiego można podeprzeć się koncepcjami już istniejącymi, choć formułowanymi dla wszystkich polskich pograniczy. Pierwszą taką propozycję przedstawiła Maria Zielińska [2003: 138-147], która przeanalizowawszy kilkaset artykułów wyodrębniła następujące obszary w badaniach pogranicza: codzienne życie mieszkańców; stereotypy i kierunki ich przeobrażeń; tożsamość, osobowość człowieka pogranicza; mniejszości narodowe, etniczne, religijne; zjawiska patologiczne. Analizując stan zastany, ale nie w odwołaniu do szerokich zasobów socjologii pogranicza, tylko na podstawie zawartości czasopisma „Pogranicze. Studia Społeczne” Zbigniew Kurcz [2010: 293-295] identyfikuje następujące pograniczne tematy pojawiające na tych łamach: tożsamość i identyfikacje narodowe; mniejszości narodowe; teoretyczne ramy rozważań nad pograniczem; stosunki międzyetniczne; zróżnicowanie religijne; sąsiedztwo narodowe; refleksje nad kształtowaniem się i rozwojem; struktura narodowościowa; miasta przygranicza i pogranicza; migracje i rodzina na pograniczu; pogranicze historyczne. W tym samym tekście autor przypomina swoje wcześniejsze [Kurcz 2008: 24-26] propozycje systematyzacji obszarów, na których koncentrować winna się socjologia pogranicza. Ujęte hasłowo prezentują się następująco: analiza ruchu granicznego: wielkość, kierunek, charakter; struktura gospodarki - branże; aktywność podmiotów gospodarczych; struktura etniczna i stosunki międzyetniczne; rozmiar i charakter przestępczości; konflikty społeczne i ich aktorzy; wpływy kulturowe; małżeństwa mieszane; saldo migracji.

W trzech przedstawionych propozycjach niektóre tematy się powtarzają. Niektóre, ze względu na specyfikę pogranicza zachodniego i jego wyraźną odrębność od pogranicza wschodniego, nie mogą być aplikowane do badań tego pierwszego. Korzystając ze zgłoszonych propozycji postaram się wskazać na problemy podejmowane w refleksji nad pograniczem polsko-niemieckim, łącząc poszczególne w szersze zbiory i czasami nowe konfiguracje. Kategoriami najbardziej ogólnymi, w które wpisują się węziej definiowane tematy badawcze są: refleksja nad kształtowaniem się $i$ rozwojem pogranicza oraz, wchodzące w zakres poprzedniej kategorii, życie codzienne mieszkańców. Kolejne rozstrzygnięcia są dość arbitralne i dyskusyjne. Proponowałabym bowiem włączyć w zakres ogólnej refleksji nad kształtowaniem się i rozwojem pogranicza takie tematy, jak: gospodarka na pograniczu, transgraniczna współpraca instytucjonalna, ideologie, tożsamość, świadomość i zachowania mieszkańców, młodzieży i elit, demografia oraz pamięć. W ramach tego najszerzej zdefiniowanego problemu badawczego mieści się również życie codzienne mieszkańców, do której to 
kategorii proponowałabym przypisać następujące wątki badawcze: miasta przygranicza i pogranicza, sąsiedztwo narodowe, stereotypy, zjawiska patologiczne. Umowność zaproponowanego porządku wynika z samej natury badanej i opisywanej rzeczywistości, wszak procesy zachodzące w miastach podzielonych silnie rzutują na rozwój pogranicza polsko-niemieckiego, a na przykład ideologie obecne na pograniczach są wyraźnie obecne w przestrzeniach miast podwójnych.

Najliczniej reprezentowana jest refleksja na temat codziennego praktykowania pogranicznego sąsiedztwa, która skupia się na relacjach społecznych między Polakami i Niemcami, mieszkańcami miast podzielonych (np. gubinianami i gubenianami), rodzaju kontaktów, w które wchodzą. Przebieg i następstwa codziennego życia w bezpośredniej bliskości niemieckiego sąsiada są dostrzegane na bazarach, w inicjatywach dotyczących ochrony środowiska, obserwowane (np. w organizacjach i na ulicach) w postępującej dyfuzji kulturowej oraz mechanizmach dostosowawczych rynku pracy. Jednym z kontekstów pogranicznej codzienności jest stan pogranicznej świadomości mieszkańców (postrzeganie bliskości granicy, konsekwencji zmian jej funkcji, świadomościowego waloryzowania i obecności sąsiadów, pamięci historycznych losów zamieszkiwanych ziem i ich mieszkańców).

Istotną częścią dorobku socjologii pogranicza zachodniego jest problematyka ponadgranicznej współpracy, interesująca badaczy w perspektywie jej przyczyn, przebiegu, ograniczeń, sztandarowych przedsięwzięć, ale i poziomów, na których przebiega. Część analiz ma charakter komparatystyczny i próbuje odkrywać pewne prawidłowości, zestawiając dane dotyczące poszczególnych miast, rodzajów działań i aktorów je realizujących. Współpraca instytucjonalna i nieformalna często pojawia się w kontekście tematu euromiast i euroregionów realizujących konkretne projekty, ale autorzy podnoszą także kwestie formalnych ram, szyldów, w jakie miasta i regiony się wpisują, skuteczności kreujących je ideologii dających się odczytać w zderzeniu oficjalnych i formalnych haseł z masowym i codziennym ich odbiorem przez mieszkańców. Wątkiem powiązanym z poprzednimi jest tożsamość, która interesuje badaczy w ujęciu przygranicznym, regionalnym, ale i transgranicznym, w różnych częściach pogranicza i odmiennych perspektywach temporalnych.

Wyraźnie dostrzegalna w całym omawianym dorobku jest refleksja nad młodzieżą, która w zamyśle autorów, jako socjalizująca się na nowym pograniczu polsko-niemieckim, stanowić ma probierz zaistnienia efektu pogranicza. Dlatego też interesujące dla badaczy pogranicza zachodniego są postawy, orientacje i aspiracje życiowe młodzieży, jej charakterystyka 
społeczno-demograficzna, ukształtowany w socjalizacji system aksjonormatywny, ale również zachowania ekonomiczne i pozaszkolna aktywność. Być może tak duża liczba publikacji jest również funkcją dostępności badanych i jest to okoliczność sprzyjająca ich powstawaniu.

Dużo miejsca poświęcono zjawiskom patologicznym, które są specyficzne dla pogranicza tworzonego przez kraje o różnym poziomie ekonomicznym i odrębnym prawodawstwie. Sytuacja ta stwarza charakterystyczne warunki dla pojawienia się rozmaitych rodzajów przestępczości w nietypowym natężeniu; niektóre z zaobserwowanych patologii swoiście się instytucjonalizują, a ich postrzeganie i definiowanie przez mieszkańców odbiega od wzorca obserwowanego w innych częściach kraju.

Stosunkowo często autorzy powracają do kwestii stereotypowego postrzegania sąsiada. Korzystając z metodologii ilościowych i jakościowych nie tylko rejestrują wzajemne postrzeganie się sąsiadów, kształt obrazu uogólnionych Niemców, ale i bardziej „konkretnych” mieszkańców drugich części miast podzielonych, w perspektywie dwudziestopięcioletniej widać już zachodzące $\mathrm{w}$ procesie stereotypizacji zmiany.

Ważnym zjawiskiem dostrzeganym przez socjologów i podejmowanym w publikacjach jest również demografia. Szczególnych właściwości pogranicza zachodniego poszukuje się również w cechach (i ich dynamicznej charakterystyce) jego mieszkańców - demograficznych, ale i tych, które konstytuują człowieka pogranicza.

\section{Zakończenie}

Podsumowując zaprezentowane dane i ich analizę należy raz jeszcze podkreślić ograniczony charakter wniosków z nich wypływających, są one bowiem konsekwencją zastosowanego doboru próby - bardziej lub mniej restrykcyjnie przeprowadzona selekcja uwzględnionych publikacji mogłaby skorygować rozkłady zmiennych. Jest to oczywista konsekwencja problemów z definiowaniem pogranicza oraz sporu o przedmiot socjologii pogranicza i dokonanych w tej materii rozstrzygnięć.

Ilościowe spojrzenie na dorobek socjologii pogranicza polsko-niemieckiego zachęca do mówienia o jego doniosłości - niemal dwieście publikacji, prawie stu autorów. Jednak twierdzenie to wychodziłoby poza opartą na empirii, ale jednak intuicję, gdyby charakterystyki te, dotyczące przecież tylko jednego pogranicza, porównać z danymi opisującymi pozostałe (choć w przypadku pogranicza zachodniego, nawet pobieżny, niepoparty systematycznymi studiami, ogląd sytuacji obrazuje większe zaangażowanie 
badaczy niż na pozostałych unijnych pograniczach: polsko-czeskim, polsko-słowackim, polsko-litewskim). Mimo iż nie było przedmiotem analizy porównywanie tego pogranicza $\mathrm{z}$ innymi, to ważne jest, aby na zakończenie podkreślić jego specyfikę, ponieważ przesłanka ta wydaje się ważnym kontekstem dla wyprowadzanych wniosków.

Kilka okoliczności uprzywilejowuje kierowanie zainteresowań badawczych na zachodnie pogranicze. Po pierwsze, należałoby powiedzieć o roli i znaczeniu Niemiec oraz Unii Europejskiej przed, i po wstąpieniu Polski do struktur europejskich oraz NATO (co wyrażało się choćby w finansowaniu ponadgranicznej współpracy głównie z dedykowanych jej programów) i w konsekwencji o kierowaniu na pogranicze polsko-niemieckie specjalnego zainteresowania. Specyfika wspomnianego „laboratorium”, odróżniająca pogranicze zachodnie od pozostałych, polega również na tym, że działają tu cztery euroregiony i istnieje wiele podzielonych granicą państwową układów osadniczych, które bardziej niż „teren pomiędzy” prowokują badania. Dodatkowe finansowanie, znaczenie polityczne, nasycenie euroregionami i miastami podzielonymi przekładało się na „intensywność” tego pogranicza i aktywność badaczy.

Wracając do wielkości omawianego dorobku, i mając na uwadze zgłaszaną powyżej niebagatelną rolę odgrywaną przez analizowane pogranicze w kontekście rozwoju subdyscypliny, pamiętać również należy, że większą jego część napisało [zaledwie?] czternastu socjologów. Jak na rangę, funkcje i znaczenie, jakie pogranicze polsko-niemieckie pełni w polskiej rzeczywistości oraz fakt, że znajduje się ono w strefie zainteresowań co najmniej czterech ośrodków naukowych, jak należy ocenić liczbę badaczy, którzy zajmują się nim systematycznie i dogłębnie?

Tematy poruszane przez socjologów zajmujących się pograniczem polsko-niemieckim są również funkcją jego cech charakterystycznych. Większość z nich dotyczy relacji transgranicznych, doświadczania niemieckiego sąsiada $\mathrm{w}$ różnych momentach i sytuacjach codziennego życia oraz towarzyszących im procesów świadomościowych. Ważne są jednak również tematy, które się nie pojawiają. Brak analiz poświęconych problematyce grup mniejszościowych (etnicznych, narodowych i religijnych) wynika $\mathrm{z}$ faktu, że jest to nadal pogranicze stykowe, administracyjne, a nie przejściowe, kulturowe. Być może to również wytłumaczenie niewielkiego zainteresowania kwestiami tożsamości - rodzaj napięć konstytuujących identyfikacje przygraniczne lub ponadgraniczne $\mathrm{w}$ obszarze oddziaływania granicy na Odrze i Nysie jest bowiem z pewnością odmienny od tych obecnych na innych polskich pograniczach, szczególnie wschodnich. Poza tym, wobec 
obserwowanego od dłuższego czasu boomu memoryzacyjnego, zastanawia również mała liczba opracowań podejmujących problematykę pamięci.

W ostatnim zdaniu warto przypomnieć, że nie bez znaczenia dla kształtu dorobku socjologii pogranicza polsko-niemieckiego jest organizacyjnotechniczny wymiar uprawiania nauki. Podejmowane problemy są po części pochodną możliwości pozyskiwania danych - badania częściej realizowane są w łatwiej dostępnych obszarach, takich jak miasta podzielone lub wśród młodzieży (Zgorzelec, Gubin oraz Słubice stanowiły przedmiot zainteresowania 15-20\% opracowań, 4\% zajmuje Krosno Odrzańskie; 15\% dotyczyło młodzieży $\left.{ }^{6}\right)$. Gros osiągnięć jest publikowanych w specjalistycznych czasopismach i tomach zbiorowych, co ogranicza szerszy rezonans w dyskursie naukowym, ale też czyni ten zbiór łatwo dostępnym.

\section{Bibliografia}

Gołdyka L. (2013), Pogranicze polsko-niemieckie jako przestrzeń socjalizacji, Warszawa.

Kurcz Z. (1998), Czy i jak badać dzisiaj Ziemie Zachodnie i Pótnocne Polski?, „Przegląd Zachodni", nr 3.

Kurcz Z. (2011), Z pogranicza na pogranicze..., $z$ pogranicza na transgranicze... i $z$ powrotem? Kierunki i charakter przemian na polskich pograniczach, [w:] Z. Kurcz, Polskie pogranicza $w$ procesie przemian, t. 2, Wałbrzych.

Sakson A. (2002), Wspótczesne badania socjologiczne na Ziemiach Zachodnich i Pótnocnych - stare i nowe wyzwania, [w:] K. Bondyra, K. Lisiecki (red.), Odmiany polskich tożsamości, Poznań .

Sakson A. (2011), Przemiany tożsamości lokalnej i regionalnej mieszkańców Ziem Zachodnich i Pólnocnych, [w:] A. Michalak, A. Sakson, Ż. Stasieniuk (red.), Polskie Ziemie Zachodnie. Studia socjologiczne, Poznań.

Zielińska M. (2003), Socjologiczne badania empiryczne na terenach pogranicznych. Między teoria a praktyka, [w:] M. Zielińska, Transgraniczność w perspektywie socjologicznej. Teorie, studia, interpretacje, t. 1, Zielona Góra.

$6 \quad$ Kilka cech może odnosić się do jednej publikacji. 


\section{SUMMARY}

\section{Polish-German borderland in sociological reflection in twenty-five years perspective}

The article covers the area of twenty-five years scientific outputs in Sociology regarding the Polish-German borderland. The data on which the analysis is based are 192 publications which has been classified by the author into the universe of analytical texts referring to the area mentioned above.

Results of analyses presented in the publication firstly indicate a sustainable rate of growth of knowledge and analysis in subsequent years, secondly allow to notice high concentration of articles in multiply-authors monographies - in comparison much to those coming from magazines and shows prevalence of fourteen scientists as authors of about $60 \%$ of overall number of publications.

Leading areas of sociological consideration on the Polish western frontier microcosm can be identified as research on the creation and development of the borderland society, daily life of its inhabitants, explorations of frontier cities, national neighborhood, stereotypes, low-life cases.

KEYWORDs: Polish-German borderland, publications, sociologists 